\title{
Diversifikasi Pasar dan Daya Saing Ekspor Produk Olahan Kopi Indonesia ke Negara Emerging Market Terpilih
}

\author{
(Market Diversification and Export Competitiveness of Indonesian Coffee Products to Emerging \\ Market Countries)
}

\author{
Mukhlisul Amal Mustofa ${ }^{1 *}$, Achmad Syahrul Choir ${ }^{2}$ \\ 1,2 Politeknik Statistika STIS \\ Jl. Otto Iskandardinata No.64C, Jatinegara, Jakarta Timur \\ E-mail: ${ }^{2} 211709871 @$ stis.ac.id, ${ }^{2}$ madsyair@stis.ac.id
}

\begin{abstract}
ABSTRAK
Ekspor kopi Indonesia hingga kini masih didominasi oleh biji kopi, tetapi nilai ekspor biji kopi terus menurun. Sebaliknya, ekspor Produk Olahan Kopi Indonesia (POKI) cenderung meningkat selama periode 2015-2019. Namun, ekspor POKI masih didominasi ke satu negara, yaitu Filipina, sehingga ekspornya sangat terpengaruh dengan kondisi negara tersebut. Hal ini menyebabkan ekspor POKI rentan tidak stabil. Oleh karena itu, perlu dilakukan diversifikasi pasar terhadap ekspor POKI. Penelitian ini bertujuan untuk menganalisis tingkat diversifikasi pasar ekspor POKI dan daya saing ekspornya ke beberapa negara emerging market tujuan diversifikasi selama periode 2010-2019. Ukuran yang digunakan yaitu Indeks Hirschman, Revealed Comparative Advantage, Export Product Dynamic, dan X-Model. Hasilnya, diketahui bahwa diversifikasi pasar ekspor POKI secara agregat belum cukup baik. Selain itu, daya saing ekspor POKI ke beberapa negara tujuan emerging market sudah cukup baik dengan posisi yang strategis. Berdasarkan hasil X-model, diperoleh lima negara yang secara optimis dapat menjadi tujuan diversifikasi.
\end{abstract}

Kata kunci: Produk Olahan Kopi, Diversifikasi Pasar Ekspor, Revealed Comparative Advantage, Export Product Dynamic, X-Model

\begin{abstract}
Indonesia's coffee exports are still dominated by coffee beans, but the export value has decreased. In contrast, exports of Indonesian Coffee Products (POKI) tend to increase during 2015-2019. However, POKI's exports are still dominated by one country, namely the Philippines, so its exports are greatly affected by the condition of that country. This causes POKI exports to be vulnerable to instability. Therefore, it is necessary to diversify the market for POKI exports. This study analyzes the level of diversification of POKI's export market and its export competitiveness to several emerging market countries for diversification purposes during 2010-2019. The measures used are Hirschman Index, Revealed Comparative Advantage, Export Product Dynamic, and X-Model. As a result, POKI's export market diversification in aggregate has not been good enough.The competitiveness of POKI's exports to several emerging market destination countries is quite good with a strategic position. The results of the X-model, obtained five countries that can optimistically become the destination of diversification.
\end{abstract}

Keywords: Coffee Products, Export Market Diversification, Revealed Comparative Advantage, Export Product Dynamic, $X$-Model

\section{PENDAHULUAN}

Salah satu komoditas ekspor utama Indonesia di bidang pertanian adalah kopi. Kopi menjadi komoditas hasil alam yang termasuk dalam daftar komoditas utama ekspor selama periode 2016-2021 (Kemendag, 2021). Hal ini terlihat dari ekspor kopi yang berkontribusi sekitar 50 persen di sektor pertanian selama periode 20122019 (BPS, 2020). Mengacu ke Peraturan Menteri Perdagangan No 10/M-DAG/PER/5/2011 tentang ketentuan ekspor kopi, terdapat dua kelompok barang yang diatur dalam ekspor kopi di Indonesia, yaitu kategori biji kopi dan kategori produk olahan kopi. Namun, ekspor kopi di Indonesia masih didominasi biji kopi mentah. Hal ini ditunjukkan oleh volume ekspor kopi Indonesia pada tahun 2019 yang delapan puluh persen di antaranya berasal dari biji kopi mentah (UN Comtrade, 2020). Sayangnya, hingga kini nilai ekspor biji kopi Indonesia berfluktuasi dan cenderung kurang bersaing di pasar internasional (Sahat et al., 2016). Selain itu, fakta menunjukkan bahwa nilai ekspor biji kopi Indonesia cenderung menurun selama periode 2015-2019 (UN Comtrade, 2020). Ini sejalan dengan hipotesis Prebisch-Singer (1950) yang menyatakan nilai tukar perdagangan (trem of trade) terhadap ekspor barang primer atau mentah akan menurun (Kemendag, 2014). 
Berbeda dengan ekspor biji kopi, nilai ekspor Produk Olahan Kopi Indonesia (POKI) cenderung mengalami peningkatan dan memiliki nilai jual lebih tinggi daripada hasil biji kopi mentah (Kemendag, 2018).

Meskipun ekspor POKI mengalami peningkatan, tetapi masih terdapat permasalahan dalam ekspor POKI tersebut. Pasar ekspor POKI diduga belum terdiversifikasi dengan baik. Terlihat bahwa lebih dari 50 persen share nilai ekspor POKI masih bergantung pada mitra utama, yaitu Filipina (Gambar 1a). Terdapat perbedaan share nilai ekspor yang cukup besar antara Filipina dan negara-negara lainnya. Perbedaan ini bahkan meningkat dari tahun 2015 ke 2019 (Gambar 1(a)). Selain itu, pertumbuhan ekspor POKI ke Filipina dan ke negara-negara lain pada tahun 2019 menurun dibandingkan satu dekade sebelumnya (Gambar 1(b)). Penurunan pertumbuhan ekspor ke Filipina yang cukup besar terjadi di tahun 2013, sejalan dengan perlambatan ekonomi Filipina yang berada pada titik terendah di antara negara anggota ASEAN lainnya (Asmara, 2013). Hal tersebut menunjukkan bahwa ekspor POKI rentan tidak stabil karena kinerja ekspornya dapat terpengaruh oleh guncangan ekonomi di negara mitra utama tersebut.

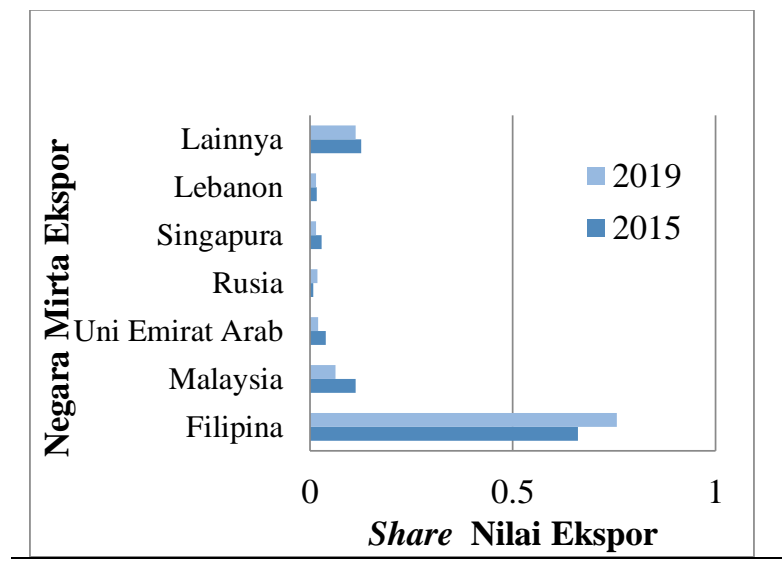

(a)

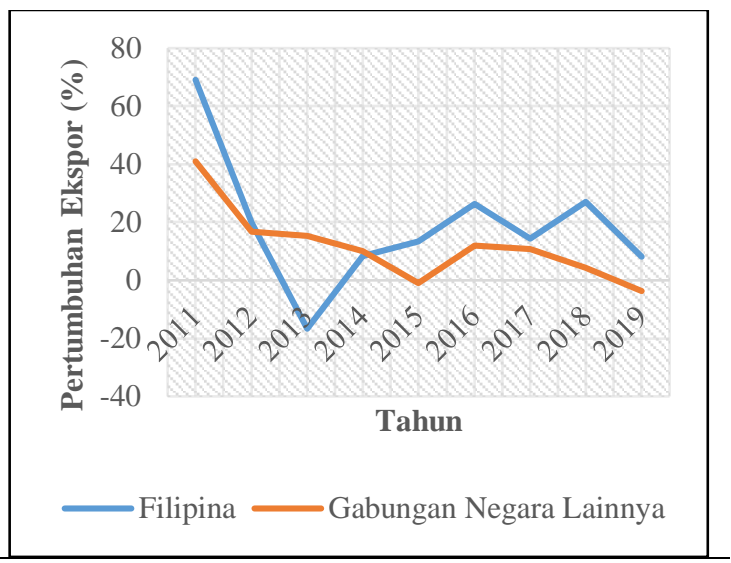

(b)

Sumber: www.comtrade.un.org, diolah

Gambar 1. (a) Share Nilai Ekspor Olahan Kopi Menurut Negara Mitranya Tahun 2015 dan 2019 (\%),

(b) Pertumbuhan Ekspor Produk Olahan Kopi di Indonesa ke Filipina dan negara lain tahun 2011-2019

Salah satu strategi yang dapat ditujukan untuk menstabilkan penerimaan ekspor adalah melalui adanya diversifikasi (Mejia, 2011). Oleh karena itu, Peraturan Menteri Perdagangan No 46 Tahun 2020 menetapkan bahwa salah satu strategi dari pengembangan dan perluasan ekspor Indonesia adalah melalui diversifikasi pasar. Pasar tujuan ekspor yang sebelumnya berorientasi ke negara-negara besar mitra utama pasar tradisional, kini mulai beralih pada sejumlah negara berkembang yang cukup potensial atau emerging market (Kemendag, 2013). Emerging market umumnya belum tergolong besar, tetapi potensial untuk menjadi tujuan ekspor baru (Kemendag, 2013). Oleh karena itu, berdasarkan strategi kebijakan tersebut, khususnya pada masalah ketergantungan pasar ekspor POKI ke Filipina, perlu dilakukan kajian lebih lanjut terkait diversifikasi pasar dan potensi dari setiap negara mitra ekspor tersebut sebagai prioritas tujuan diversifikasi.

Secara umum, penelitian yang terkait dengan diversifikasi ekspor POKI masih terbatas. Penelitian yang ada masih menggabungkan antara komoditi POKI maupun biji kopi. Sahat et al. (2016) mengkaji terkait pengembangan ekspor kopi di Indonesia, baik dalam bentuk biji kopi, kopi sangrai maupun POKI. Fokus penelitian Sahat et. al. (2016), mengkaji bentuk diversifikasi ekspor di bidang kopi dengan metode dekomposisi ekspor. Hasilnya, ekspor kopi Indonesia masih didominasi biji kopi mentah sedangkan ekspor POKI mulai muncul mengalami diversifikasi dan dapat mendorong pertumbuhan ekspor setelah tahun 2006.

Karena belum banyak penelitian terkait, penelitian ini berfokus pada diversifikasi ekspor pasar POKI dan daya saingnya. Penelitian ini bertujuan untuk menganalisis tingkat diversifikasi pasar ekspor produk olahan kopi Indonesia periode 2010-2019 dan mengkaji tingkat daya saing dan performa ekspor dinamis produk olahan kopi Indonesia ke negara-negara emerging market tujuan diversifikasi periode 2010-2019.

Untuk menganalisis diversifikasi, penelitian ini mengunakan ukuran Indeks Hirschman (IH). Ukuran ini dipakai oleh beberapa peneliti dan paling banyak digunakan dalam berbagai kajian (Amir et al., 2018). IH diterapkan oleh Haryotejo (2015) untuk menganalisis diversifikasi pasar ekspor komoditas udang Indonesia. Penelitian tersebut menunjukkan bahwa pasar ekspor udang Indonesia belum terdiversifikasi dengan baik dan indeks spesialisasi masih tinggi. Selain itu, IH juga diterapkan oleh Birol Erkan (2017) untuk menganalisis diversifikasi produk dan pasar ekspor di Turki. Hasil penelitiannya menunjukkan pasar ekspor di Turki berhasil diterapkan cukup baik, sebaliknya diversifikasi produk ekspornya belum cukup berhasil. Adapun Amir (2018) 
mengkaji diversifikasi ekspor menggunakan IH dan pengaruhnya terhadap pertumbuhan ekonomi di ASEAN. Hasilnya, ditunjukkan bahwa diversifikasi membawa pengaruh positif terhadap pertumbuhan ekonomi di ASEAN.

Untuk mengkaji daya saing, penelitian ini menggunakan Revealed Comparative Advantage (RCA) dan Export Prodct Dynamic (EPD), serta mengkombinasikan kedua ukuran tersebut melalui klasterisasi X-Model. Ukuran-ukuran tersebut diterapkan oleh Nurhayati et al. (2019) yang mengkaji daya saing ekspor pala, lawang, dan kapulaga. Hasil penelitian tersebut menunjukkan bahwa ekspor Indonesia optimis di empat negara tujuan dan lima negara tujuan menunjukan ekspor yang potensial saja. Selain itu, Puruwita dan Oktora (2019) mengkaji daya saing ekspor kayu lapis Indonesia ke tiga negara tujuan utama dengan menggunakan RCA dan EPD. Hasilnya, ditemukan bahwa RCA kayu lapis Indonesia tidak stabil dan tidak sejalan dengan volume ekspornya. Adapun berdasarkan EPD, posisi ekspor berada di kelompok Falling Star ketika berada di negara tujuan AS dan posisi Retreat di dua negara tujuan, yaitu Jepang dan Korea Selatan.

\section{METODE}

\section{Diversifikasi Pasar Ekspor}

Menurut Kamus Besar Bahasa Indonesia (KBBI), diversifikasi adalah bentuk penganekaragaman, yaitu usaha untuk menghindari ketergantungan pada ketunggalan kegiatan, produk, jasa atau investasi (KBBI, 2008). Mengacu pada Kemendag (2014), diversifikasi pasar ekspor merupakan strategi yang mendorong kemajuan ekspor yang dari awal bersifat tradisional (berfokus ke mitra pasar utama) kepada ekspor yang bersifat nontradisional, yaitu pasar yang berkembang dan potensial untuk ekspor atau pasar yang belum tersentuh. Untuk mengukur tingkat diversifikasi, penelitian ini mengacu pada ukuran concentration ratio karena ukuran tersebut secara luas telah banyak digunakan oleh berbagai peneliti (Amir et al., 2018). Ukuran tersebut yaitu IH yang mengukur konsentrasi pasar produk olahan kopi secara agregat (Erkan, 2017).

Indeks diversifikasi IH mengukur secara agregat konsentrasi ekspor pasar produk pada suatu waktu (Haryotejo, 2013) dan menunjukkan distribusi negara, apakah ekspor pasar terkonsentrasi atau terdivesifikasi (low concentration) (Erkan, 2017). Ukuran ini juga banyak digunakan secara luas (Tegene, 1990) dan penting digunakan dalam perbandingan antar periode (Kovács, 2004). Indeks Hirschman dihitung dengan persamaan

$$
\mathrm{IH}_{t}=\sqrt{\sum_{i=1}^{n_{w}}\left(\frac{X_{o, i t}}{\sum_{i}^{n_{w}} X_{o, i t}}\right)^{2}},
$$

dengan $I H_{t}$ adalah indeks Hirschman POKI pada periode waktu ke- $t$. $X_{o, i t}$ menunjukkan ekspor POKI menurut negara mitra $k e-i$, dan $n_{w}$ adalah total negara mitra ekspor. Nilai indeks ini berada pada rentang nol hingga satu. Oleh sebab itu, semakin mendekati nilai nol maka akan semakin terdiversifikasi.

\section{Revealed Comparative Advantage)}

Salah satu indikator tingkat daya saing, yang digunakan untuk mengukur keunggulan komparatif komoditas suatu negara terhadap negara lain di tujuan pasar suatu negara adalah Revealed Comparative Advantage (RCA) (Hasibuan et al,, 2012). Nilai RCA yang lebih besar dari satu menunjukkan bahwa daya saing produk tersebut tergolong kuat. Sebaliknya, nilai RCA yang lebih kecil dari satu menunjukkan bahwa daya saing produk tergolong lemah (Mudjayani, 2008 dalam Haryotejo, 2013). RCA dihitung dengan persamaan (Rahardjo et al., 2020)

$$
R C A_{i}=\frac{X_{o, i} / X_{T E, i}}{X_{o w, i} / X_{T E w, i}},
$$

dengan $X_{o, i}$ adalah nilai ekspor POKI ke negara $i, X_{T E, i}$ adalah total ekspor seluruh komoditas Indonesia ke negara $i, X_{o w, i}$ adalah nilai ekspor produk olahan kopi dunia ke negara $i, \operatorname{dan} X_{T E w, i}$ adalah total nilai ekspor seluruh komoditas dunia ke negara $i$.

\section{Export Prodct Dynamic}

EPD merupakan salah satu indikator yang mengukur daya saing untuk melihat posisi ekspornya. Salah satu keunggulan dari EPD adalah dapat mengukur posisi pasar dan dinamis atau tidaknya suatu produk di pasar tujuan negara ekspor (Hasibuan, et al, 2012). EPD dianalisis ke dalam empat kategori yang dikelompokkan dalam matriks posisi daya saing antara share ekspor suatu negara dalam perdagangan dunia (share of country's export in world trade) dan share produk ekspor dalam perdagangan dunia (share of product in world trade) (Tabel 1). Untuk lebih jelas mendeskripsikannya, EPD digambarkan dalam suatu kuadran dengan sumbu X 
merepresentasikan kekuatan pasar atau pangsa pasar dan sumbu Y merepresentasikan daya tarik pasar dari suatu produk.

$$
\begin{aligned}
X^{*} & =\frac{\sum_{t=1}^{T}\left(\frac{X_{T E, i}}{X_{T E w, i}}\right)_{t} \times 100 \%-\sum_{t=1}^{T}\left(\frac{X_{T E, i}}{X_{T E w, i}}\right)_{t-1} \times 100 \%}{10} \\
Y^{*} & =\frac{\sum_{t=1}^{T}\left(\frac{X_{o, i}}{X_{o w, i}}\right)_{t} \times 100 \%-\sum_{t=1}^{T}\left(\frac{X_{o, i}}{X_{o w, i}}\right)_{t-1} \times 100 \%}{T} \ldots .
\end{aligned}
$$

dengan $X^{*}$ adalah nilai di sumbu $\mathrm{X}$ dan $Y^{*}$ nilai di sumbu $\mathrm{Y}$.

Tabel 1. Matriks Posisi Daya Saing dengan Metode EPD.

\begin{tabular}{cccc}
\hline No & Share of Country's Export in World Trade & \multicolumn{2}{c}{ Share of Product World Trade } \\
\cline { 3 - 4 } & & Rising Star (Dynamic) & Falling (Stagnant) \\
\hline 1. & Rising (Competitive) & Rising Star & Falling Star \\
2. & Falling (Non-competitive) & Lost Opportunity & Retreat \\
\hline
\end{tabular}

Sumber : Esterhuizent (2006)

\section{X-Model}

Metode X-Model ini mengkombinasikan antara hasil analisis RCA dengan hasil analisis EPD dalam suatu bentuk pengelompokan (klasterisasi) tujuan ekspor/pasar dengan maksud untuk memfokuskan pasar perdagangan (Nurhayati et al., 2019). Salah satu keunggulan metode X-Model ini, yaitu dapat memperoleh hasil analisis daya saing yang dikaji menjadi lebih komprehensif karena melihat daya saing komoditas dari dua sisi sekaligus, yaitu dari sisi RCA dan juga EPD (Mubarokah, 2020).

Tabel 2. Model Keputusan X-Model.

\begin{tabular}{ccc}
\hline RCA & EPD & Klaster X-Model \\
\hline RCA $>1$ & Rising Star & Pasar Optimis \\
& Lost Opportunity & Pasar Potensial \\
& Falling Star & Pasar Potensial \\
& Retreat & Kurang Potensial \\
RCA $<1$ & Rising Star & Pasar Potensial \\
& Lost Opportunity & Kurang Potensial \\
& Falling Star & Kurang Potensial \\
& Retreat & Tidak Potensial \\
\hline
\end{tabular}

Sumber: Nurhayati et al. (2018)

\section{Metode Analisis}

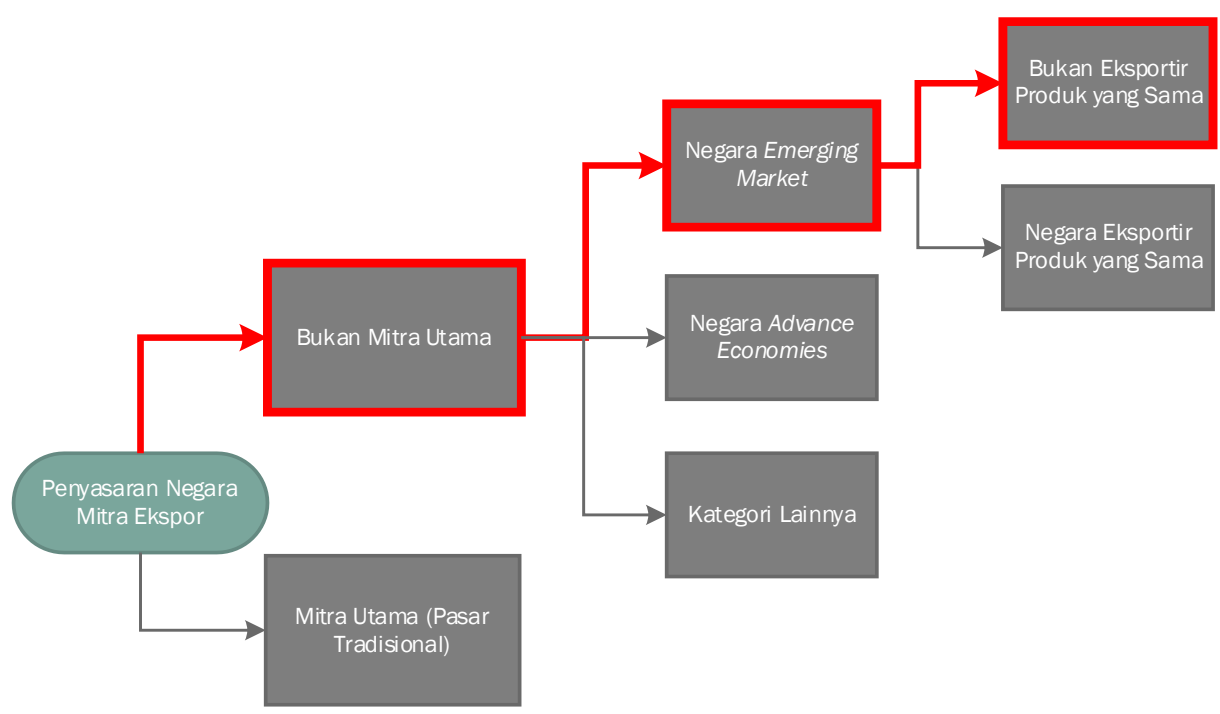

Gambar 2. Tahapan pengkategorian negara

Pengukuran dan analisis tingkat diversifikasi ekspor POKI berdasarkan ukuran IH yang telah dijelaskan pada persamaan (1). Sementara itu, negara emerging market diperoleh berdasarkan pada tahapan 
pengkategorian negara dalam Gambar 2. Pengelompokan kategori negara mengacu pada klasifikasi IMF yaitu negara Emerging Market dan negara ekonomi maju (Advance Economies) yang dimuat dalam World Ecomoic Outlook (WEO) bulan Oktober 2020 (IMF, 2020). Selain itu, negara tujuan diversifikasi dipilih dengan mempertimbangkan juga kategori lain, seperti negara eksportir produk yang sama, kategori negara mitra utama (tradisional) dengan konsentrasi ekspor tertinggi, dan kategori negara lainnya yang tidak tercakup dalam keempat kategori sebelumnya karena perbedaan klasifikasi atau negara bukan anggota IMF. Berdasarkan kriteria tersebut, diperoleh lima kategori negara tujuan ekspor produk olahan kopi yaitu Negara Mitra Utama (Tradisional), Negara Emerging Market, Negara Perkonomian Maju (Advance Economies), Negara Eksportir Produk yang sama (10 besar dunia), dan Negara Lainnya. Dari lima kategori tersebut, dipilih satu kategori yaitu negara tujuan emerging market yang menjadi objek penelitian.

\section{Data dan Sumber Data}

Penelitian ini menggunakan data panel selama periode 2010-2019 dengan lokus negara mitra ekspor produk olahan kopi tujuan diversifikasi (emerging market). Namun, untuk penghitungan indeks diversifikasi agregat, digunakan seluruh negara mitra ekspor yang ada selama periode penelitian tersebut. Sumber data sekunder diperoleh dari publikasi statistik ekspor BPS ataupun website resmi UN Comtrade, WITS, Trade Map, WorldBank, dan IMF. Adapun variabel yang digunakan sebagai analisis diversifikasi dan daya saing ekspor yaitu nilai ekspor produk olahan kopi dan nilai total ekspor seluruh komoditas.

\section{HASIL DAN PEMBAHASAN}

\section{Pasar Ekspor Produk Olahan Kopi Indonesia}

Pola diversifikasi tujuan pasar ekspor POKI cukup berkembang pesat dan bertambah setiap tahunnya selama periode 2010-2019 (Tabel 3). Penambahan jumlah pasar (negara mitra) ekspor terbesar terjadi pada tahun 2014. Namun, pada tahun 2019, terjadi penurunan jumlah mitra ekspor sebesar sembilan negara mitra. Regolo (2017) menyatakan bahwa penentuan pola tujuan pasar ekspor berdasarkan riwayat usia barang tersebut masuk pasar (diekspor) merupakan hal yang penting. Eaton et al. (2007) beranggapan bahwa perluasan ekspor barang masuk ke pasar luar negeri dapat terjadi dalam jangka waktu kurang lebih satu dekade. Berdasarkan hal tersebut, dari Tabel 3 diperoleh jumlah mitra tetap ekspor produk olahan kopi Indonesia sebanyak 26 negara selama satu dekade terakhir. Meskipun jumlah mitra bertambah dan bervariasi setiap tahunnya, hal ini tidak menjamin mitra tersebut sebagai mitra ekspor tetap. Selanjutnya, 26 negara tersebut dikelompokkan terlebih dahulu ke dalam lima kelompok negara (berdasarkan tahapan Gambar 2) sehingga diperoleh negara emerging market terpilih untuk analisis penentuan negara tujuan diversifikasi.

Tabel 3. Perkembangan Negara Mitra Ekspor Produk Olahan Kopi Indonesia Periode 2010-2019

\begin{tabular}{ccccc}
\hline \multirow{2}{*}{ Tahun } & \multirow{2}{*}{ Jumlah Negara Mitra } & \multicolumn{3}{c}{ Perubahan Jumlah Mitra Ekspor } \\
\cline { 3 - 4 } & 47 & 7 & Berkurang & Tetap \\
2010 & 47 & 9 & 7 & 40 \\
2011 & 48 & 13 & 12 & 38 \\
2012 & 65 & 23 & 6 & 33 \\
2013 & 79 & 26 & 12 & 31 \\
2014 & 82 & 16 & 13 & 29 \\
2015 & 84 & 14 & 12 & 28 \\
2016 & 87 & 14 & 11 & 28 \\
2017 & 89 & 12 & 10 & 28 \\
2018 & 80 & 8 & 17 & 26 \\
2019 & & & & \\
\hline
\end{tabular}

Sumber: www.comtrade.un.org, diolah

Dari 26 negara mitra tetap tersebut, berdasarkan tahapan di Gambar 2, negara mitra ekspor dibagi dalam lima kelompok. Kelompok satu adalah mitra utama ekspor POKI yaitu Filipina. Kelompok dua adalah negara yang tergolong perekonomian maju (Advance Economies) yang terdiri atas Jerman, Belgia, Selandia Baru, Kanada, Hongkong, Amerika Serikat (AS), Australia, Republik Korea, Jepang, dan Singapura. Kelompok tiga adalah kategori negara yang tergolong eksportir produk olahan kopi. Batasan yang diambil pada negara ekportir produk olahan kopi dipilih berdasarkan peringkat negara yang berada di sepuluh besar eksportir produk olahan kopi dunia yaitu Vietnam dan Malaysia. Kelompok empat adalah negara emerging market yang dipilih sebagai negara tujuan diversifikasi. Negara tersebut terdiri atas Uni Emirat Arab, Rusia, Lebanon, Cina, Papua Nugini, Thailand, Saudi Arabia, Yordania dan Pakistan. Kelompok lima adalah negara kategori lainnya. 
Negara-negara tersebut tidak termasuk dalam kategori emerging market dan bukan advance economies karena perbedaan dasar klasifikasi yaitu Brunei dan Iran sebagai negara produsen minyak (oil producers) dan Samoa (negara di Oseania).

\section{Tingkat Diversifikasi Pasar Ekspor dan Share Export}

Mengacu Gambar 3, tingkat konsentrasi pasar ekspor produk olahan kopi Indonesia relatif stabil serta cenderung mengalami peningkatan (menaik). Pada periode 2010-2019, nilai IH berada di rentang 0,647 hingga 0,76. Menurut pedoman Divisi Anti-Trust Departemen Kehakiman AS nilai indeks rasio konsentrasi yang diatas 0,25 sudah dapat diindikasikan bahwa adanya konsentrasi yang tinggi (Kelly, 2015). Oleh karena itu, indeks menunjukkan bahwa pasar ekspor produk olahan kopi Indonesia secara agregat masih terkonsentrasi (Erkan, 2017). Dengan demikian, dapat dikatakan bahwa pasar ekspor produk olahan Indonesia belum terdiversifikasi dengan baik. Peningkatan tingkat diversifikasi terbesar terjadi pada tahun 2018, yaitu sebesar 0,038 poin. Hal ini dikarenakan pada tahun tersebut terjadi peningkatan terbesar pada ekspor olahan kopi Indonesia ke Filipina, yaitu sebesar 89,25 juta dolar AS di tahun tersebut (UN Comtrade 2020).

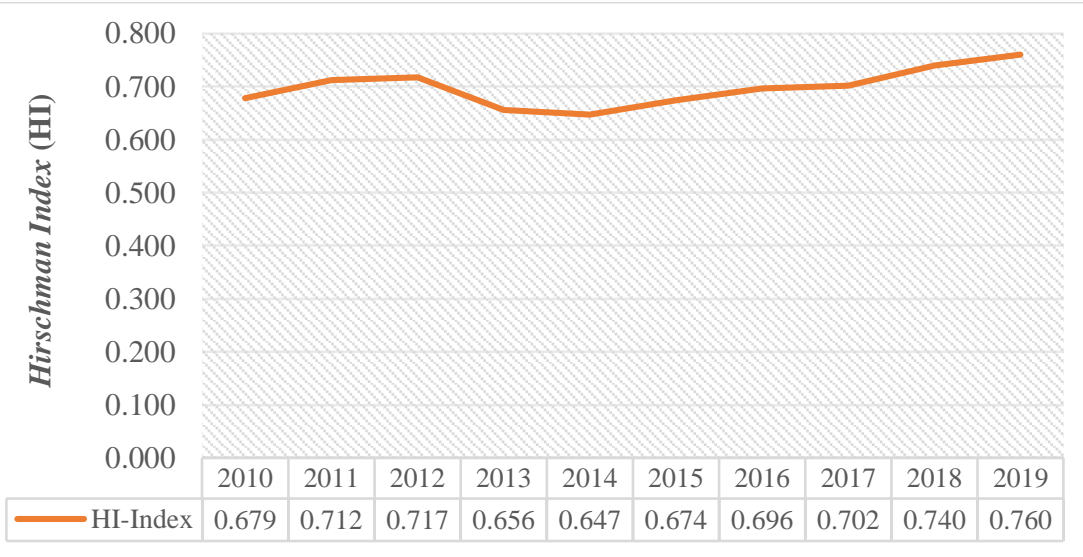

Sumber: $\underline{\text { www.trademap.org, diolah }}$

Gambar 3. Ukuran diversifikasi pasar Hirschman Index

Untuk mendapatkan gambaran negara-negara mitra ekspor POKI, pangsa pasar (share) ekspornya dikaji berdasarkan lima kelompok yang telah ditentukan untuk melihat potensi dari masing-masing kelompok negara tersebut. Gambar 4 menunjukkan share ekspor POKI (Gambar 4(a)) dan ekspor seluruh komoditas (total ekspor (Gambar 4(b)). Berdasarkan perbandingan kedua gambar tersebut, dapat dinilai kemungkinan suatu negara menjadi tujuan diversifikasi pasar POKI berdasarkan rekam jejak ekspornya.

Mengacu Gambar 4, share ekspor negara mitra utama ekspor POKI (Filipina) paling tinggi dibandingkan negara lainnya, yaitu mencapai 80 persen dari ekspor POKI. Selain itu, sebagian besar negara advance economies memiliki share ekspor yang sangat kecil pada ekspor produk olahan kopi. Dipandang dari total ekspornya, beberapa negara maju, seperti Jepang, Singapura, AS, dan Korea Selatan, memiliki share ekspor yang tinggi yaitu menduduki peringkat lima besar importir Indonesia. Hal ini sejalan dengan kerja sama ekonomi Indonesia yang cukup kuat di negara tersebut karena sudah tergolong sebagai klaster pasar tradisional Indonesia sejak lama (Sabaruddin, 2017). Negara tersebut berpotensi menjadi pasar ekspor POKI karena memiliki rekam jejak sebagai importir bagi Indonesia. Namun, cakupan penelitian ini hanya kategori negaranegara emerging market. Sementara itu, negara emerging market yang dipilih sebagai negara tujuan diversifikasi, masih memiliki share ekspor produk olahan kopi yang rendah. Namun jika dilihat dari total ekspor, beberapa negara memiliki share ekspor cukup tinggi dan berpotensi menjadi negara pengimpor produk olahan kopi. Hal ini ditunjukaan oleh Cina dan Thailand serta beberapa negara timur tengah lainnya (Pakistan, Uni Emirat Arab, dan Saudi Arabia) yang cukup strategis dari segi total ekspor seluruh komoditasnya meskipun memiliki share ekspor yang rendah pada ekspor produk POKI (Gambar 4). Negara-negara tersebut berpotensi sebagai sasaran ekspor sebab sudah terdapat riwayat dan rekam jejak aktivitas ekspor Indonesia yang cukup baik di negara tersebut. Oleh karena itu, kondisi tersebut dapat mendorong adanya kesempatan dan potensi bagi ekportir dari Indonesia untuk lebih gencar dalam mengekspor produk olahan kopi di negaranegara emerging market tersebut. 


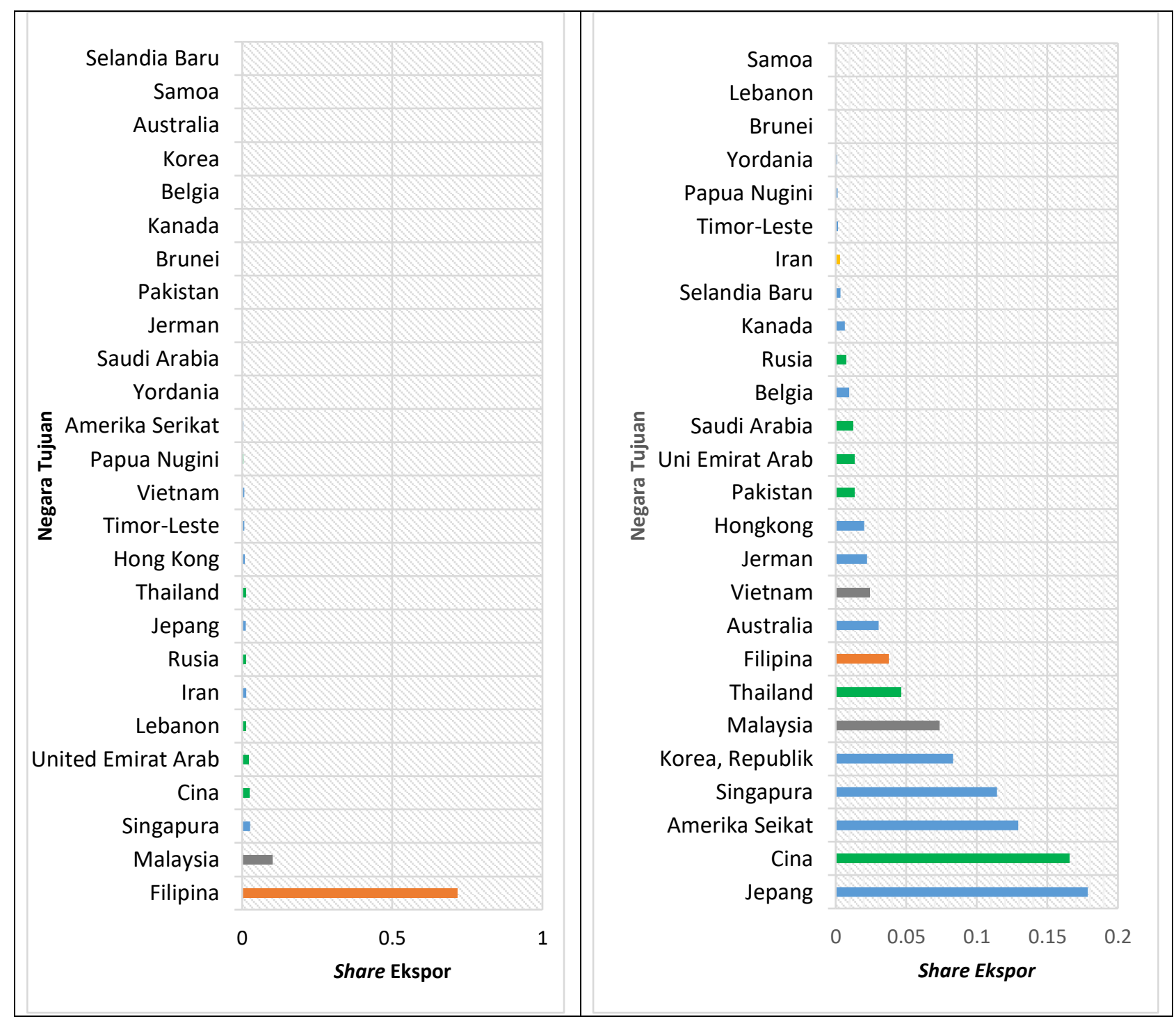

(a)

(b)

Sumber: wits.worldbank.org, diolah

Gambar 4. Pangsa (Share) ekspor setiap negara: (a) Ekspor POKI, (b) Ekspor total (seluruh komoditas)

Keterangan:

\begin{tabular}{|l|l|}
\hline & Mitra Utama (Tradisional) \\
\hline & Negara Perekonomian Maju \\
\hline & Eksportir 10-besar dunia \\
\hline & Emerging Market Terpilih \\
\hline & Tidak Masuk Kategori \\
\hline
\end{tabular}

\section{Daya Saing Ekspor Produk Olahan Kopi Indonesia ke Negara Emerging Market}

Analisis daya saing ekspor dilakukan dengan menggunakan RCA dan EPD. Gambar 4 menyajikan RCA POKI dan mengkomparasikannya dengan dua negara eksportir besar, yaitu Jerman dan Brazil, yang menduduki posisi tiga besar eksportir produk olahan kopi dunia. Berdasarkan Gambar 4, dapat dilihat bahwa RCA POKI di negara emerging market tujuan diversifikasi cenderung banyak berfluktuasi selama periode 2010 hingga 2019 (garis jingga). Sebagai salah satu eksportir tiga besar dunia, Indonesia memiliki nilai keunggulan komparatif yang cukup tinggi dengan rata-rata di atas nilai satu serta menguasai di beberapa negara yaitu Uni Emirat Arab, Lebanon, Cina, Thailand dan Yordania. Namun, Indonesia menempati keunggulan daya saing di posisi kedua setelah Brazil saat berada dalam pasar Rusia, Saudi Arabia dan Pakistan. Sementara itu, RCA ke Papua Nugini tidak dapat disajikan karena keterbatasan data yang tersedia. Selain itu, data UN Comtrade (2020) menunjukkan bahwa Jerman dan Brazil tidak melakukan ekspor produk olahan kopi ke Papua Nugini sehingga Indonesia merupakan satu-satunya eksportir ke negara tersebut. 


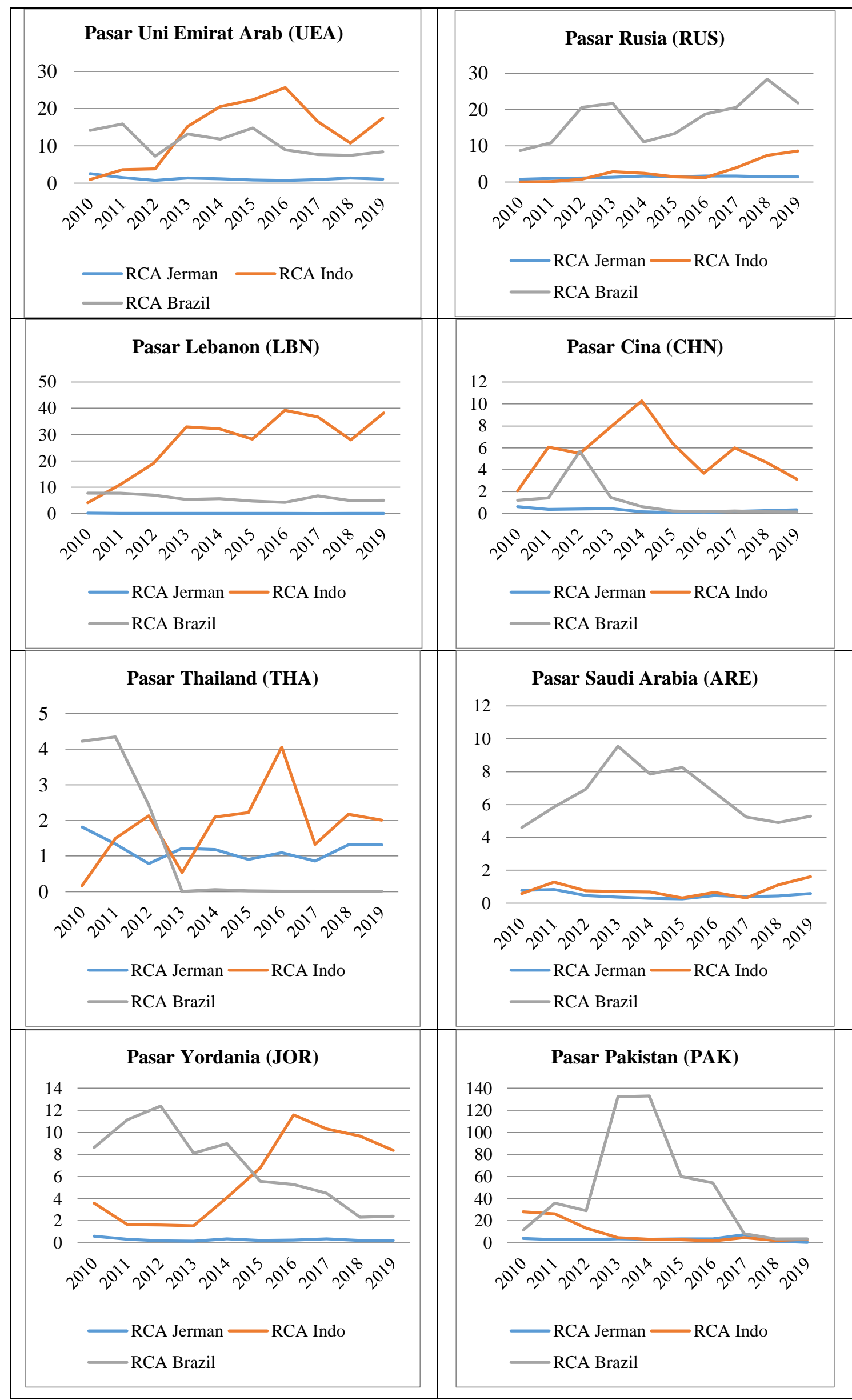

Sumber: www.comtrade.un.org, diolah

Gambar 5. RCA olahan kopi Indonesia dan dua eksportir terbesar di delapan negara 


\section{Export Product Dynamic (EPD)}

Daya saing EPD (Gambar 5) menunjukaan bahwa terdapat lima negara yang menduduki posisi ideal (Rising Star) untuk menjadi tujuan ekspor produk olahan kopi Indonesia, yaitu Papua Nugini, Lebanon, Thailand, Rusia, dan Cina. Artinya, ekspor Indonesia di negara tersebut cukup diminati karena terjadi penambahan share pasar yang bertumbuh cepat (fast-growing product) (Muharami dan Novianti, 2018). Sementara itu, daya saing ekspor produk olahan kopi Indonesia di Uni Emirat Arab, Saudi Arabia dan Yordania menunjukkan posisi Lost Opportunity yang berarti produk olahan kopi Indonesia masih diminati meskipun pangsa pasar tidak menunjukkan peningkatan dan sisanya di Pakistan menunjukkan posisi Falling Star yang berarti produk olahan kopi Indonesia di negara tersebut kurang diminati (stagnan).

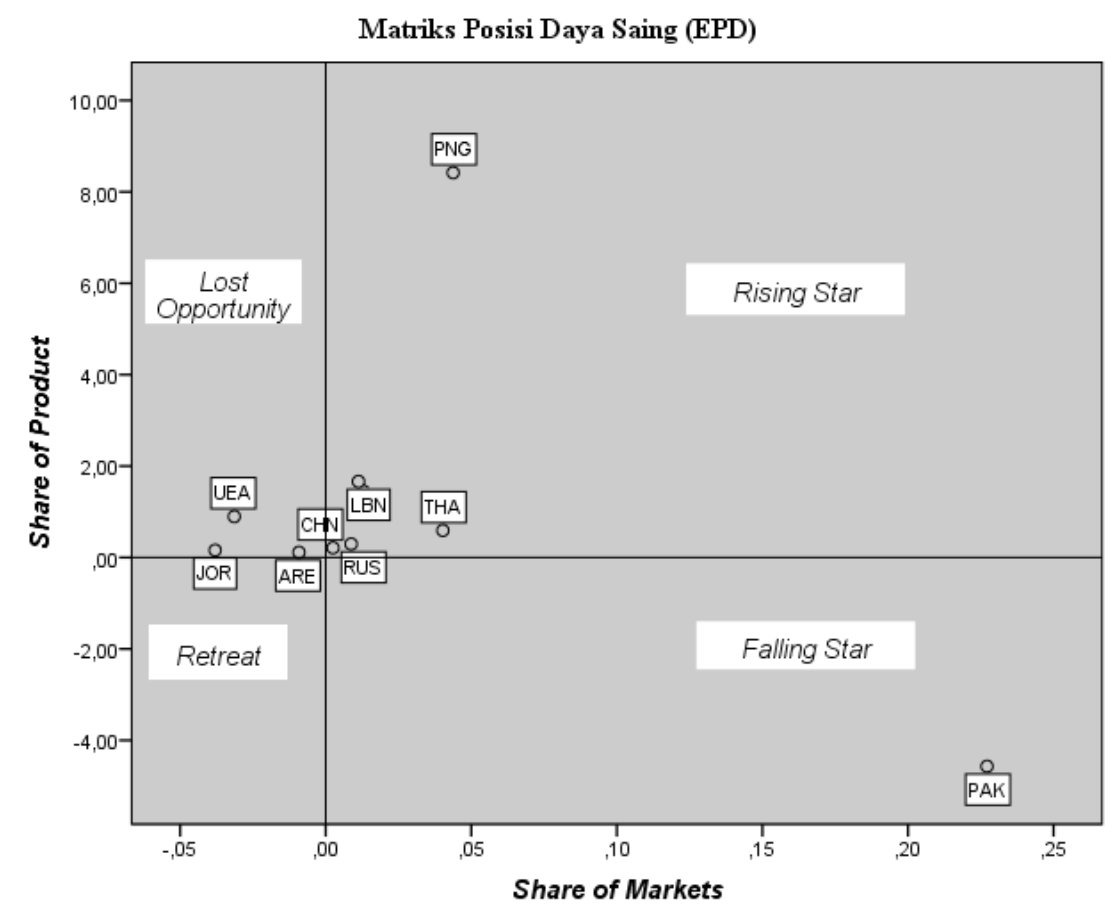

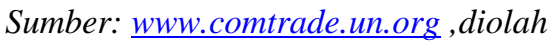

Gambar 6. Kuadran daya saing produk olahan kopi Indonesia (EPD)

Tabel 4. Hasil Klasteriasi X-Model

\begin{tabular}{crcc}
\hline Negara & RCA & EPD & Klaster X-Model \\
\hline Uni Emirat Arab & 13,705 & Lost Opportunity & Pasar Potensial \\
Rusia & 2,867 & Rising Star & Pasar Optimis \\
Lebanon & 27,019 & Rising Star & Pasar Optimis \\
Cina & 5,569 & Rising Star & Pasar Optimis \\
Papua Nugini & 7,097 & Rising Star & Pasar Optimis \\
Thailand & 1,819 & Rising Star & Pasar Optimis \\
Saudi Arabia & 0,798 & Lost Opportunity & Kurang Potensial \\
Yordania & 5,921 & Lost Opportunity & Pasar Potensial \\
Pakistan & 15,836 & Falling Star & Pasar Potensial \\
\hline
\end{tabular}

Sumber: Hasil Pengolahan

Berdasarkan Tabel 4, ekspor produk POKI memiliki potensi pengembangan pada klaster pasar optimis di lima negara tujuan, yaitu Rusia, Lebanon, China, Papua Nugini, dan Thailand. Hal ini ditunjukkan dengan ekspor POKI memiliki daya saing yang kuat (RCA $>1)$ dan sekaligus berada pada posisi ideal (Rising Star) di lima negara tersebut. Lalu, di tiga negara tujuan, yaitu Uni Emirat Arab, Yordania, dan Pakistan ekspor POKI memiliki potensi pengembangan dengan klaster pasar yang potensial. Terakhir, di satu negara tujuan Saudi Arabia ekspor POKI memiliki potensi pengembangan pasar pada klaster yang kurang potensial. Ini disebabkan oleh adanya daya saing ekspor ke negara tersebut yang lemah (RCA dibawah satu) dan posisi ekspor yang kurang menguntungkan karena kehilangan pangsa pasar ekspor (Lost Opportunity) (Nurhayati et al., 2018). 


\section{KESIMPULAN}

Pasar ekspor POKI selama periode 2010-2019 masih relatif terkonsentrasi dan cenderung makin meningkat setiap tahunnya. Ini menunjukkan bahwa diversifikasi pasar ekspor POKI selama periode 20102019 belum cukup baik dan perlu adanya upaya peningkatan diversifikasi pasar ke negara-negara potensial selain mitra utamanya (Filipina). Berdasarkan RCA, EPD, dan X-Model diperoleh bahwa daya saing ekspor POKI ke sembilan negara emerging market tujuan diversifikasi cukup baik dengan posisi yang strategis. Dari sembilan negara emerging market tersebut, diperoleh lima negara tujuan emerging market yang memiliki potensi pengembangan pasar optimis sebagai tujuan diversifikasi yaitu Rusia, Lebanon, China, Papua Nugini, dan Thailand. Oleh karena itu, sebagai upaya pengembangan ekspor POKI, sebaiknya pemerintah memprioritaskan peningkatan diversifikasi ke lima negara yang memiliki potensi pengembangan optimis tersebut sehingga kerentanan ekspor POKI menjadi tidak stabil dapat dikurangi.

\section{DAFTAR PUSTAKA}

Amir, F., Dedi Budiman Hakim, dan Tanti Novianti. (2018). Dampak Diversifikasi Ekspor Terhadap Pertumbuhan Ekonomi Negara-Negara Anggota ASEAN. Jurnal Ekonomi Dan Kebijakan Pembangunan, 7(2), 118-139.

Asmara, A. A. (2013). Ekonomi ASEAN: Pertumbuhan Melambat, Perbaikan Tidak Secepat Harapan. Macroeconomic Dashboard.

BPS. (2020). Analisis Komoditas Ekspor, 2012-2019, Sektor Pertanian, Industri dan Pertambangan .

Eaton, J., Eslava, M., Kugler, M., dan Tybout, J. (2007). Export growth in Colombia: firm-level evidence. Econpapers.Repec.Org, February, 10-11. http://econpapers.repec.org/RePEc:bdr:borrec:446

Erkan, B. (2017). Product and Market Diversification in Turkey's Foreign Trade. International Journal of Advances in Management and Economics Vol 3(1), 10-15

Esterhuizent, D. (2006). Competitiveness Of The South Africa Agribusiness Sctor. Department of Agricultural Economics. Extension and Rural Development Faculty of Natural and Agricultural Science. University of Pretoria

Haryotejo, B. (2015). Analisa Diversifikasi Pasar Ekspor Komoditi Udang Indonesia. Jurnal Sosial Ekonomi Kelautan Dan Perikanan, 8(1), 85. https://doi.org/10.15578/jsekp.v8i1.1199

Hasibuan, A. M., Nurmalina, R., dan Wahyudi, A. (2012). Analisis Kinerja dan Daya Saing Perdagangan Biji Kakao dan Produk Kakao Olahan Indonesia di Pasar Internasional. The American Political Science Review, 92(3).

IMF. (2020). Mitigating Climate Change - Growth- and Distribution-Friendly Strategies. In World Economic Outlook: A Long and Difficult Ascent.

Kelly, A. (2015). Measuring research competitiveness in UK universities. Assessment and Evaluation in Higher Education, 41(8), 1206-1222. https://doi.org/10.1080/02602938.2015.1074979

Kemendag. (2013). Peluang dan Tantangan Ekspor ke Negara-Negara Nontradisional. Direktorat Jenderal Pengembangan Ekspor Nasional (DJPEN)

Kemendag. (2021). Perkembangan Ekspor NonMigas (Komoditi). https://statistik.kemendag.go.id/growth-ofnon-oil-and-gas-export-commodity

Kemendag. (2014). Kajian Penyusunan Target Ekspor Impor Indonesia 2015-2019 Pusat Kebijakan Perdagangan Luar Negeri.

Kovács, Z. Á. (2004). Is There Any Convergence in Trade Structures Following EU Accession? - Some Trade Related Aspects of Enlargement. In Economic Research, Marketing and Computing.

Mejia, J. F. (2011). Export Diversification and Economic Growth: An Analysis of Colombia's Export Competitiveness in the European Union's Market. Springer. http://www.springer.com/series/1262

Muharami, G., dan Novianti, T. (2018). Analisis Kinerja Ekspor Komoditas Karet Indonesia Ke Amerika Latin. Jurnal Agribisnis Indonesia, 6(1), 15-26.

Nurhayati, E., Hartoyo, S., dan Mulatsih, S. (2018). Pengembangan Pasar Ekspor Lada Indonesia. Buletin Ilmiah Litbang Perdagangan, 12(2), 267-288.

Nurhayati, E., Hartoyo, S., dan Mulatsih, S. (2019). Analisis Pengembangan Ekspor Pala, Lawang, dan Kapulaga Indonesia. Jurnal Ekonomi Dan Pembangunan Indonesia, 19(2), 173-190. https://doi.org/10.21002/jepi.v19i2.847

Puruwita, I., dan Oktora, S. I. (2019). Exports and Competitiveness of Indonesian Plywood. 98(Icot), 108112. 
Rahardjo, B., Akbar, B. M. B., Iskandar, Y., dan Shalehah, A. (2020). Analysis and strategy for improving Indonesian coffee competitiveness in the international market. BISMA (Bisnis Dan Manajemen), 12(2), 154.

Regolo, J. (2017). Author's Accepted Manuscript Manufacturing Export Diversification and Regionalization of Trade : Which Destinations for Newly Exported Goods? International Economics.

Sabaruddin, S. S. (2017). Penguatan Diplomasi Ekonomi Indonesia Mendesain Clustering Tujuan Pasar Ekspor Indonesia: Pasar Tradisional vs Pasar Non-Tradisional. Jurnal Ilmiah Hubungan Internasional, 12(2), 205.

Sahat, S. F., Nuryartono, N., dan Hutagaol, M. P. (2016). Analisis pengembangan ekspor kopi di indonesia. Jurnal Ekonomi Dan Kebijakan Pembangunan, 5(1), 63-89.

Tegene, A. (1990). Commodity Concentration and Export Earnings Instability: The Evidence from African Countries. American Economist, 34(2), 55-59. https://doi.org/10.1177/056943459003400208 